\title{
A cooperação judiciária como técnica de gestão processual para a modificação de competência visando evitar decisões conflitantes
}

\author{
Judicial cooperation as a procedural management technique for modifying jurisdiction to avoid \\ conflicting decisions
}
La cooperación judicial como técnica de gestión procesal para la modificación de competencia para evitar decisiones contradictorias

\author{
Rosalina Moitta Pinto da Costa \\ ORCID: https://orcid.org/0000-0002-3673-6912 \\ Universidade Federal do Pará, Brasil \\ E-mail: rosalinacosta@ufpa.br
}

\begin{abstract}
Resumo
O trabalho analisa a cooperação judiciária como técnica de gestão processual para a modificação de competência a fim de evitar decisões conflitantes. Utilizando o método dedutivo com revisão doutrinária como opção metodológica, analisa-se a cooperação judiciária como técnica capaz de dar concretude ao princípio da eficiência, pela modificação de competência. Como os atos de cooperação, permitindo o diálogo institucional entre juízes e órgãos do Poder Judiciário para responder às situações concretas, caracterizam-se pela falta proposital de um regramento predefinido pelo legislador, conclui-se que os atos de cooperação que visam a reunião de processos, ainda que estejam autorizados pelo sistema processual, importam em uma nova forma de modificação de competência como atos de gestão processual que são, para respeitar o princípio da eficiência processual.
\end{abstract}

Palavras-chave: Cooperação judiciária; Competência; Eficiência; Ato concertado; Gestão processual.

\begin{abstract}
The paper analyzes judicial cooperation as a procedural management technique for the modification of jurisdiction in order to avoid conflicting decisions. Using the deductive method with doctrinal revision as a methodological option, judicial cooperation is analyzed as a technique capable of giving concrete effect to the principle of efficiency, by modifying competence. As the acts of cooperation, allowing institutional dialogue between judges and bodies of the Judiciary to respond to specific situations, are characterized by the deliberate lack of a rule predefined by the legislator, it is concluded that the acts of cooperation aimed at meeting processes, even though they are authorized by the procedural system, they import in a new form of modification of competence as acts of procedural management that are, to respect the principle of procedural efficiency.
\end{abstract}

Keywords: Judicial cooperation; Competence; Efficiency; Concerted act; Procedural management.

\section{Resumen}

El trabajo analiza la cooperación judicial como una técnica de gestión procesal para la modificación de la jurisdicción con el fin de evitar decisiones contradictorias. Utilizando el método deductivo con la revisión doctrinal como opción metodológica, se analiza la cooperación judicial como técnica capaz de concretar el principio de eficiencia, modificando la competencia. Como los actos de cooperación, que permiten el diálogo institucional entre jueces y órganos del Poder Judicial para dar respuesta a situaciones específicas, se caracterizan por la falta deliberada de una norma predefinida por el legislador, se concluye que los actos de cooperación orientados a atender procesos, incluso si bien están autorizados por el sistema procesal, importan en una nueva forma de modificación de competencia como actos de gestión procesal que son, para respetar el principio de eficiencia procesal.

Palabras clave: Cooperación judicial; Competencia; Eficiencia; Acto concertado; Gestión procesal.

\section{Introdução}

A crise do Judiciário, causada principalmente pela ampliação do acesso à justiça, especialmente a partir do último quartel do século passado, levou à necessidade de se buscarem novas técnicas de gerenciamento visando o aperfeiçoamento da prestação jurisdicional pelos juízes. 
De acordo com o relatório Justiça em números 2020, o Poder Judiciário finalizou o ano de 2019 com 77,1 milhões de processos (Conselho Nacional de Justiça [CNJ], 2020, p. 5). Mas o mais importante desse relatório foi o fato de apontar a extraordinária taxa de casos solucionados que o Poder Judiciário alcançou. Conforme o relatório, o volume de processos baixados atingiram, em 2019, o maior valor da série histórica.

Durante o ano de 2019, em todo o Poder Judiciário, ingressaram 30,2 milhões de processos e foram baixados 35,4 milhões. Houve um aumento de 11,6\% nos casos solucionados, tendo sido registrado o maior índice de produtividade dos magistrados em toda a série histórica de mensuração, iniciada em 2009. Isso significa que, em 2019, os magistrados brasileiros apresentaram sua melhor produtividade nos últimos onze anos (CNJ, 2020, p. 93).

Não obstante, o ano foi finalizado com 77 milhões de processos, apesar de todo o empenho (CNJ, 2020, p. 150). E as perspectivas não são nada animadoras, principalmente em razão da situação pandêmica. Com tudo o que se vivencia neste cenário pandêmico, o número de processos tende a crescer muito mais, o que só reforça a necessidade de buscar outros caminhos, outras formas de gestão.

Nesse contexto, a cooperação judiciária nacional, como técnica de gestão processual, permitindo o diálogo entre os juízes e órgãos do Poder Judiciário, possibilita traçar coletivamente uma política judiciária adequada para responder com eficiência às situações concretas, viabilizando uma tutela jurisdicional mais célere e efetiva.

Este trabalho analisa a cooperação judiciária como técnica de gestão capaz de dar efetividade ao princípio da eficiência pela modificação de competência, mediante o diálogo entre juízes e órgãos do Poder Judiciário.

Iniciando com o estudo da eficiência, apresenta a cooperação judiciária como uma técnica capaz de dar efetividade ao princípio da eficiência, pela modificação de competência.

Em seguida, constatando-se que os atos de cooperação consubstanciam-se em atos de gestão atípicos, cuja realização, por visar à solução ótima de cada processo e à efetividade do funcionamento do Judiciário, não dispõe de regras procedimentais predeterminadas, estuda-se a modificação da competência para evitar decisões conflitantes por ato de cooperação judicial como técnica de concretude do princípio da eficiência processual.

Ao final, conclui-se que os atos de cooperação que visam à reunião de processos são atos únicos ou permanentes (concertados). Ainda que estejam autorizados pelo sistema processual, importam em uma nova forma de modificação de competência com as especificidades de atos de gestão processual que são, para satisfazer ao princípio da eficiência processual.

Como opção metodológica, este trabalho recorre ao método dedutivo com revisão doutrinária.

\section{Metodologia}

A pesquisa será desenvolvida por meio do método dedutivo, no qual as premissas sustentam de modo completo a conclusão (Marconi \& Lakatos, 2003, p. 92).

Na presente análise, partindo da premissa de que os atos de cooperação consubstanciam-se em atos de gestão atípicos sem regras procedimentais predeterminadas, verifica-se a hipótese da cooperação judiciária, como técnica de gestão processual, com o objetivo de investigar a modificação da competência para evitar decisões conflitantes por ato de cooperação judicial como técnica de concretude do princípio da eficiência processual.

A pesquisa pode ser classificada como qualitativa, pois é um meio de análise de um fenômeno dentro do contexto em que é inserido, buscando o entendimento do fenômeno como um todo, na sua complexidade (Godoy, 1995, p. 62), elaborandose hipóteses, considerando a impossibilidade de quantificação de dados em casos tais como o enfrentado (Pereira, Shitsuka, Parreira, \& Shitsuka, 2018). 
Investigou-se, sob tal perspectiva, a cooperação judiciária nacional, como técnica de gestão processual que permite traçar coletivamente uma política judiciária adequada para responder com eficiência às situações concretas, viabilizando, na situação preconizada de modificação de competência por atos de cooperação, uma tutela jurisdicional mais célere e efetiva.

Utilizar-se-á o método bibliográfico para a investigação, baseado em pesquisa de doutrina, jurisprudência e legislação vinculada ao objeto de estudo.

\section{Resultados e Discussão}

\subsection{A gestão processual como técnica que dá concretude ao princípio da eficiência processual}

A eficiência pressupõe a realização de finalidades predeterminadas segundo os meios empregados para tanto. Estrutura o modo como a administração deve atingir os seus fins e determina a intensidade da relação entre as medidas adotadas e os objetivos perseguidos (Ávila, 2005, p. 19). Relaciona-se, portanto, com a adoção de meios para o atendimento de finalidades previamente estabelecidas. "Haverá eficiência se os meios adotados forem ótimos, gerando pouco esforço ou dispêndio, com o melhor resultado possível"1. Ser eficiente é adotar medidas satisfatórias para alcançar finalidades preestabelecidas. A eficiência presume o exercício ótimo das prerrogativas estatais para a consecução do interesse público (Ferreira, 2019, p. 13).

Embora o conceito de eficiência não seja primordialmente jurídico, não se pode separá-lo do que as demais ciências primeiramente estatuíram (Rodrigues \& Porto, 2018, p. 91-93): visa alcançar as finalidades estabelecidas pelo ordenamento com a maior qualidade e os menores gastos possíveis.

Oriundo do direito administrativo², o princípio da eficiência surge na Administração Pública para regular a atuação dos agentes públicos. A eficiência, aplicada no âmbito da Administração Pública, exige condutas que produzam o efeito desejado, com a obtenção de um bom resultado, respeitadas a finalidade pública, a legalidade, a isonomia e a moralidade (Cunha, 2014, p. 74).

Com a Emenda Constitucional (EC) n. ${ }^{\circ}$ 19, de $1988^{3}$, que implementou a reforma administrativa, iniciada em 1995, visando atender objetivos políticos e sociais, foi inserido o princípio da eficiência no caput do artigo 37 da Constituição Federal (CF) como diretriz da Administração Pública.

Embora já houvesse referências à eficiência no texto constitucional originário nos artigos 74, II, e 144, § 7. .4, somente com a previsão no caput do artigo 37 da CF, o princípio da eficiência passou a marcar a atuação dos agentes públicos e a ditar a organização, a estrutura e a disciplina da Administração Pública (Cunha, 2014, p. 70-71). Até então, ainda que já houvesse dispositivo estabelecendo a observância do princípio da eficiência no processo administrativo federal ${ }^{5}$, não havia menção a esse princípio no Código de Processo Civil (CPC) de 1973, nem previsão de sua aplicação no âmbito do processo judicial.

\footnotetext{
1 A eficiência diferencia-se da eficácia. "Enquanto a eficácia é a aptidão para produzir efeitos, a efetividade constitui uma medida de concretização dos efeitos previstos na norma" (Cunha, 2014, p. 67).

2 O princípio da eficiência constitui norma de Direito Administrativo, fundamentando as regras de gestão administrativa do Poder Judiciário. Nesse sentido: Campos, 2018, p. 9, Cunha, 2014, p. 74, Didier Jr., 2017, p. 115.

3 EC n. ${ }^{\circ}$ 19, de 4 de junho de 1998: "Modifica o regime e dispõe sobre princípios e normas da Administração Pública, servidores e agentes políticos, controle de despesas e finanças públicas e custeio de atividades a cargo do Distrito Federal, e dá outras providências".

$4 \mathrm{O}$ artigo 74, II, da CF/88 dispõe que "os Poderes Legislativo, Executivo e Judiciário manterão, de forma integrada, sistema de controle interno com a finalidade de comprovar a legalidade e avaliar os resultados, quanto à eficácia e eficiência, da gestão orçamentária, financeira e patrimonial nos órgãos e entidades da administração federal, bem como da aplicação de recursos públicos por entidades de direito privado". O artigo 144 , § 7. , da CF/88 estabelece caber à lei "disciplinar a organização e o funcionamento dos órgãos responsáveis pela segurança pública, de maneira a garantir a eficiência de suas atividades".

5 A Lei n. ${ }^{\circ}$ 9.784, de 29 de janeiro de 1999, que regula o processo administrativo no âmbito da administração pública federal, estabelece, no seu artigo 2 . $^{\text {, que }}$ "a Administração Pública obedecerá, dentre outros, aos princípios da legalidade, finalidade, motivação, razoabilidade, proporcionalidade, moralidade, ampla defesa, contraditório, segurança jurídica, interesse público e eficiência".
} 
Com o advento do CPC de 2015 e a inserção no artigo 8. ${ }^{\circ}$ da eficiência como um dos princípios que integram as normas fundamentais do processo civil, o princípio da eficiência passa a reger a administração dos órgãos e a atuação dos agentes públicos no âmbito do Poder Judiciário, desbordando no processo judicial.

Como visto, o princípio da eficiência surge na Administração Pública para regular a atuação dos agentes públicos e, no âmbito do Poder Judiciário, é endereçado à administração dos órgãos que o compõem. Portanto, a eficiência, que era inerente à atividade administrativa, espraia-se pela atividade jurisdicional, levando ao processo civil as mesmas conotações do princípio da eficiência na Administração Pública: máximo atingimento das finalidades (qualitativa e quantitativamente) com o menor esforço (Rodrigues \& Porto, 2018, p. 99).

Podem-se, então, identificar dois aspectos da eficiência no sistema processual ${ }^{6}$ : a) um aspecto quantitativo, que estaria relacionado com a velocidade dos procedimentos e a redução de $\operatorname{custos}^{8}$; b) um aspecto qualitativo, que visaria a adoção de técnicas adequadas para obter uma melhor qualidade das decisões.

Logo, a eficiência não se resume à celeridade, mas importa em que os métodos empregados pela atividade jurisdicional sejam racionalizados, otimizados. Consubstancia-se no princípio da razoável duração do processo (CF, art. 5. LXXVIII, e CPC 2015, art. 4. ${ }^{\circ}$ ), que preconiza a prestação da tutela jurisdicional no tempo necessário para a efetivação do direito material (Lunardi, 2018, p 31).

Para se atingir a eficiência - que é a capacidade de prestação de uma tutela jurisdicional adequada às necessidades do direito material, com o menor custo possível, garantindo a adequada participação das partes e o respeito aos direitos fundamentais $^{9}$-, são necessários mecanismos de gestão de processos que possam ser dinâmicos e flexíveis, a fim de promoverem o bom desenvolvimento do processo.

Desse modo, a eficiência, que compreende a relação entre tempo do processo e qualidade da decisão, pressupõe técnicas de gestão interna do processo. Não se trata apenas do uso adequado da técnica processual, mas também da gestão interna do processo. A aplicação concorde da técnica processual permite a adequação dos direitos que requerem uma tutela diferenciada, mas isso não basta: é preciso que o juiz gerencie o processo promovendo as diligências necessárias, "recusando o que for impertinente ou meramente dilatório, [...] adotando mecanismos de simplificação e agilização processual" (Lunardi, 2018, p. 31), com a colaboração dos sujeitos processuais e dos outros órgãos do Poder Judiciário.

Pode-se então dizer que o dever de gestão é imposição do princípio da eficiência previsto no artigo $8 .^{\circ}$ do CPC (Campos, 2018, p. 136). Portanto, a aplicação das técnicas de gestão processual corresponde à observância do princípio da eficiência jurisdicional, visando a tornar o processo mais rápido, justo e menos custoso e a propiciar, como corolário, uma prestação jurisdicional efetiva. A gestão processual dá concretude ao princípio da eficiência.

\subsection{A cooperação judiciária como técnica de gestão processual}

\subsubsection{Cooperação judiciária: um diálogo institucional entre juízes e órgãos do Poder Judiciário}

A gestão processual deve ser compreendida em uma acepção ampla de gestão judicial.

A gestão judicial é um conceito amplo que diz respeito à macroestrutura da organização e da administração do sistema judicial, compreendendo tanto a organização e a administração dos tribunais (court management), quanto a gestão

\footnotetext{
${ }^{6}$ Cf.: Cunha, 2014, p. 75, Nunes, 2012, p. 256-257, Jobim, 2017, p. 137-139.
}

${ }^{7}$ Segundo Michele Taruffo (2008, p. 185 et seq.), a eficiência está relacionada com a velocidade dos procedimentos e a redução de custos (quantidade), e com a adoção de técnicas adequadas, corretas, justas (qualidade das decisões e de sua fundamentação).

8 “[...] é preciso ter cautela com as metas de produtividade estabelecidas por órgãos como o Conselho Nacional de Justiça para que a preocupação com a resolução de muitos processos (quantitativa) não prejudique a qualidade das decisões” (Ferreira, 2019, p. 14).

9 “" $[. .$.$] o direito ao processo justo requer para sua concretização efetiva adequação do processo ao direito material - adequação da tutela jurisdicional à tutela$ do direito. É preciso ter presente que compõe o direito ao processo justo o direito à tutela jurisdicional adequada dos direitos" (Marinoni, Arenhart, \& Mitidiero, 2016, p. 390). 
processual (case management), que é o plano micro da gestão judicial, pois é a gestão dos casos ou processos, pelo uso de variadas técnicas para dispor as tarefas processuais de um modo mais célere, equitativo e menos dispendioso ${ }^{10}$, a fim de racionalizar a atividade jurisdicional (Matos, Lopes, Mendes, \& Coelho, 2015, p. 234).

Há uma relação de interdependência entre a gestão organizacional e administrativa dos tribunais e a gestão do processo, uma vez que, quanto melhores forem as condições administrativas do órgão jurisdicional, com pessoal qualificado, tecnologia, orçamento bem dividido, mais eficiência haverá na prestação jurisdicional, o que acabará por repercutir diretamente na gestão do processo, ainda que sejam técnicas de gestão diversas, submetidas a distintos regimes jurídicos (Campos, 2018, p. 121-122).

Vale ressaltar que, embora não exista uma previsão expressa em nosso sistema que imponha o dever de gestão processual, como se dá no direito português ${ }^{11}$, por exemplo, esse dever pode ser extraído de vários dispositivos do nosso ordenamento processual, como a flexibilização procedimental (CPC, art. 139, VI), a calendarização do processo (CPC, art. 191), o saneamento compartilhado (CPC, art. $357, \S 3 .^{\circ}$ ), o estabelecimento de um critério cronológico de julgamento dos processos (CPC, art. 12) e - objeto deste trabalho - a criação de técnicas adequadas de solução de conflitos, mediante a cooperação entre juízes, visando estabelecer, de forma única ou concertada, procedimentos para a reunião de causas, repetitivas ou não, no mesmo juízo, ainda que não haja conexão entre elas (CPC, art. 69, § 2. $.^{\circ}, \mathrm{c} / \mathrm{c}$ art. 55, § 3..$\left.^{\circ}\right)(\mathrm{Campos}$, 2018, p. 120).

A cooperação judiciária é uma técnica de gerenciamento que permite ao juiz alcançar, diante de cada caso concreto, a prestação da tutela jurisdicional de forma mais célere e efetiva, evitando a prática de atos inúteis ou repetitivos. A cooperação judiciária pode dar-se mediante um ato entre dois ou mais juízes, entre órgãos do próprio Judiciário, ou ainda entre órgãos do Poder Judiciário e órgãos administrativos do Poder Judiciário ${ }^{12}$.

É o que traz o artigo 67 do CPC $^{13}$, ao prever que os órgãos do Poder Judiciário, estadual ou federal, especializado ou comum, em todas as instâncias e graus de jurisdição, e até mesmo os tribunais superiores podem realizar cooperação recíproca, por meio de seus magistrados e servidores, para a prática de qualquer ato processual, complementando, a Recomendação n. ${ }^{\circ}$ 350/2020-CNJ, que a cooperação interinstitucional entre os órgãos do Poder Judiciário e outras instituições e entidades pode ocorrer entre integrantes ou não do sistema de justiça ${ }^{14} 1516$.

\footnotetext{
${ }^{10}$ A gestão processual é "a intervenção conscienciosa dos actores jurisdicionais no tratamento dos casos ou processos, através de variadas técnicas com o propósito de dispor as tarefas processuais de um modo mais célere, equitativo e menos dispendioso" (Matos, et al., 2015, p. 234). Também entendem que a gestão processual está ligada ao tribunal enquanto órgão ou court management e ao conceito de gestão processual: Campos, 2018, p. 121, Mesquita, 2015, p. 79.

${ }^{11}$ Artigo $6 .^{\circ}$ do Código de Processo Civil português (Lei n. ${ }^{\circ} 41 / 2013$, de 26 de junho, retificada pela Declaração de Retificação n. ${ }^{\circ} 36 / 2013$, de 12 de agosto): "1 - Cumpre ao juiz, sem prejuízo do ónus de impulso especialmente imposto pela lei às partes, dirigir ativamente o processo e providenciar pelo seu andamento célere, promovendo oficiosamente as diligências necessárias ao normal prosseguimento da ação, recusando o que for impertinente ou meramente dilatório e, ouvidas as partes, adotando mecanismos de simplificação e agilização processual que garantam a justa composição do litígio em prazo razoável; 2 O juiz providencia oficiosamente pelo suprimento da falta de pressupostos processuais suscetíveis de sanação, determinando a realização dos atos necessários à regularização da instância ou, quando a sanação dependa de ato que deva ser praticado pelas partes, convidando estas a praticá-lo".

12 “A cooperação, por sua vez, pode ser formulada por qualquer órgão do Judiciário Nacional, em todos seus ramos (§ 3. do art. 69). Seja entre juízes de $1 .^{\circ}$ grau, entre tribunais ou entre aqueles e estes. Pode ser entre juízos de 'Justiças' diversas (federal, estadual, do trabalho, eleitoral e militar) ou de competências distintas (trabalhista, estadual, civil, criminal etc.). Pode, ainda, envolver órgãos centralizadores que exercem funções jurisdicionais específicas, a exemplo de centros ou núcleos de conciliação ou mediação, de execução, setor de distribuição etc., ou mesmo com ou entre órgãos meramente administrativos do Poder Judiciário, pois a lei não faz distinção, tanto que se refere à cooperação 'por meio de seus magistrados e servidores"” (Meireles, 2015, p. 62-63).

${ }^{13}$ Diz Edilton Meireles (2015, p. 62): "Vejam que essa regra é dirigida ao Judiciário nacional. Logo, cuida-se de regra de processo e de administração judiciária. Não se trata propriamente, em sentido restrito, apenas de regra de processo civil ou dirigida à jurisdição civil ordinária e extraordinária. Mira, em verdade, o Judiciário nacional. É regra, em verdade, que tem fundamento no art. 37 da CF, quando esta impõe à Administração Pública, incluindo os órgãos da Justiça estatal, a obediência ao princípio da eficiência”.

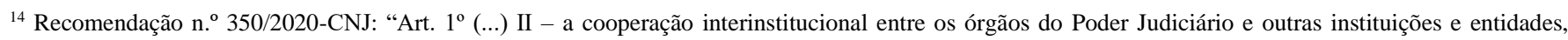
integrantes ou não do sistema de justiça, que possam, direta ou indiretamente, contribuir para a administração da justiça"

${ }^{15}$ Admitindo que pode ser celebrado ato de cooperação entre o Judiciário e um ente administrativo: Didier Jr., 2020 , p. 87.

${ }^{16}$ Admitindo que a cooperação judicial pode ocorrer entre um juízo estatal e uma câmara de arbitragem: "Embora a arbitragem não se confunda com a jurisdição, por questões ligadas à finalidade comum de soluções de controvérsia, também pode ocorrer cooperação entre órgãos jurisdicionais e tribunais arbitrais - o que se dá mediante a chamada carta arbitral (art. 69, § 1. ${ }^{\circ}$ )" (Marinoni, Arenhart, \& Mitidiero, 2017b, p. 31). No mesmo sentido: Didier Jr., 2020, p. 87.
} 
Embora sem disposição similar no CPC de 1973, a cooperação judiciária não chega a ser uma novidade em nosso sistema jurídico. A necessidade de cooperação judiciária como mecanismo “desburocratizado e ágil para o cumprimento de atos judiciais fora da esfera de competência do juízo requerente ou em intersecção com ele"17 é encontrada na Recomendação n. 38 do Conselho Nacional de Justiça (CNJ), de 3 de novembro de 2011.

O CPC de 2015, ao praticamente repetir as diretrizes da Recomendação n. ${ }^{\text {o }} 38$ do CNJ, de 2011, estatuindo uma cooperação nacional, ativa, passiva e simultânea entre os órgãos do Poder Judiciário, estadual ou federal, especializado ou comum, em todas as instâncias e graus de jurisdição, inclusive nos tribunais superiores (CPC, art. 67), reitera a necessidade de promover o diálogo institucional, a fim de que haja a interligação dos juízes, propiciando agilidade à comunicação entre os órgãos judiciários para imprimir uma maior celeridade aos atos judiciais. O novo CPC busca, assim, dotar os juízes e tribunais de poderes de melhor gestão processual, para harmonização de procedimentos forenses, tendo em vista uma prestação jurisdicional mais eficiente.

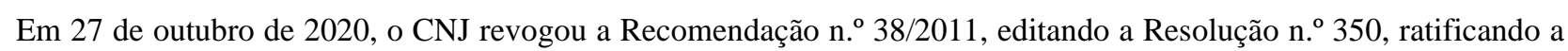
necessidade cooperação ativa, passiva e simultânea entre os órgãos do Poder Judiciário, bem como a cooperação interinstitucional entre os órgãos do Poder Judiciário e outras instituições e entidades, integrantes ou não do sistema de justiça, que possam, direta ou indiretamente, contribuir para a administração da justiça entre órgãos do Poder Judiciário para a realização de atividades administrativas e para o exercício das funções jurisdicionais (art. $1 .^{\circ}$, I e II).

A Recomendação n. 350/2020 do CNJ estabelece uma Rede Nacional de Cooperação Judiciária composta pelos Juízes de Cooperação Judiciária; Núcleos de Cooperação Judiciária de cada um dos tribunais e brasileiros; e Comitê Executivo da Rede Nacional de Cooperação Judiciária (art. 7. $^{\circ}$ ). O Juiz de Cooperação ${ }^{18}$, tem a função de interligar os juízes, imprimindo maior celeridade aos atos judiciais, a fim de dar maior fluidez e agilidade à comunicação entre os órgãos judiciários, não só para o cumprimento de atos judiciais, mas também para a harmonização e a agilização de rotinas e procedimentos forenses. Os Núcleos de Cooperação Judiciária são um espaço institucional de diálogo entre os juízes para que possam identificar problemas e características da litigiosidade de sua localidade, visando traçar coletivamente uma política judiciária adequada à realidade ${ }^{19}$. E, ao Comitê Executivo da Rede Nacional de Cooperação Judiciária, cabe organizar as ações nacionais dos núcleos de cooperação judiciária e juízes de Cooperação de todos os tribunais visando a troca de experiências, para melhorar os

\footnotetext{
${ }^{17}$ Anexo da Recomendação n. ${ }^{\text {38 }}$, de 3 de novembro de 2011, capítulo I, Disposições Gerais sobre a Cooperação Nacional.

${ }^{18}$ Recomendação n. ${ }^{\circ}$ 350/2020, capítulo V, Dos Núcleos de Cooperação Judiciária: “Art. 13. Os Juízes de Cooperação terão a função de facilitar a prática de atos de cooperação judiciária e integrarão a Rede Nacional de Cooperação Judiciária. § 1o Os Juízes de Cooperação poderão atuar em seções, subseções, comarcas, foros, polos regionais ou em unidades jurisdicionais especializadas, sendo sua esfera de atuação definida por cada tribunal. $\S 2$ o Observado o volume de trabalho, o Juiz de Cooperação poderá cumular a função de intermediação da cooperação com a jurisdicional ordinária, ou ser designado em caráter exclusivo para o desempenho de tal função. Art. 14. O Juiz de Cooperação tem por atribuições específicas: I - identificar soluções para os problemas que possam surgir no processamento de pedido de cooperação judiciária; II - facilitar a coordenação do tratamento dos pedidos de cooperação judiciária no âmbito do respectivo tribunal; III - fornecer todas as informações necessárias a permitir a elaboração eficaz de pedido de cooperação judiciária, bem como estabelecer contatos diretos entre os diversos órgãos e juízes; IV - intermediar o concerto de atos entre juízes cooperantes e ajudar na solução para problemas dele decorrentes; V - comunicar ao Núcleo de Cooperação Judiciária a prática de atos de cooperação, quando os juízes cooperantes não o tiverem feito; VI participar das comissões de planejamento estratégico dos tribunais; VII - participar das reuniões convocadas pela Corregedoria de Justiça, pelo Conselho Nacional de Justiça ou pelos juízes cooperantes; e VIII - promover a integração de outros sujeitos do processo à rede de cooperação. § 1o Sempre que um Juiz de Cooperação receber, de outro membro da rede, pedido de informação a que não possa dar o seguimento, deverá comunicá-lo à autoridade competente ou ao membro da rede mais próximo para fazê-lo. § 20 O Juiz de Cooperação deve prestar toda a assistência para contatos ulteriores".

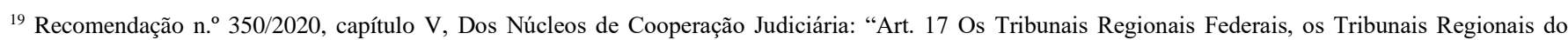
Trabalho, os Tribunais Regionais Eleitorais, os órgãos da Justiça Militar da União, os Tribunais de Justiça e os Tribunais de Justiça Militar deverão constituir e instalar, em sessenta dias, pondo em funcionamento em até noventa dias, Núcleos de Cooperação Judiciária, com a função de sugerir diretrizes gerais, harmonizar rotinas e procedimentos de cooperação, consolidar os dados e as boas práticas junto ao respectivo tribunal. Art. 18. Os Núcleos de Cooperação Judiciária serão compostos, nos tribunais, por um desembargador supervisor e por um juiz coordenador, ambos pertencentes aos quadros do rol de juízes de cooperação, podendo ser integrados também por servidores do Judiciário. Art. 19. Os Núcleos de Cooperação Judiciária poderão definir as funções dos seus Juízes de Cooperação, dividindo-as por comarcas, regiões, unidades de especialização ou unidades da Federação. § 1o Os Núcleos deverão informar ao Comitê Executivo da Rede Nacional de Cooperação Judiciária a definição das funções de cada um de seus Juízes de Cooperação, a fim de que elas constem no cadastro nacional que será gerenciado por esse Comitê. § 2o Os Núcleos deverão organizar reuniões periódicas entre os seus Juízes de Cooperação e incentivar a melhoria dos processos de cooperação judiciária com os demais Núcleos. § 3o Caberá aos Núcleos de Cooperação Judiciária de cada tribunal estabelecer critérios e procedimentos para registro de dados relevantes e boas práticas de cooperação judiciária".
} 
mecanismos de cooperação nacional pelo uso de processos e instrumentos de inovação e identificação das melhores práticas (art. 21).

Como há uma correlação entre a gestão organizacional dos tribunais e a gestão do processo, a cooperação judiciária como técnica de gestão processual pressupõe o diálogo entre os juízes e órgãos do Poder Judiciário para que possam identificar problemas e traçar coletivamente uma política judiciária adequada. A cooperação judiciária não é, portanto, um imperativo da lei, nem se trata de um direito da parte ou de um dever do julgador ${ }^{20}$. É uma faculdade do juiz em sua atribuição de gestor processual na busca de maior fluidez entre os órgãos judiciais para responder com eficiência às situações concretas. É, enfim, ato que depende do juiz, em um juízo de ponderação, analisando o caso concreto em interligação com os demais juízes e órgãos do Poder Judiciário.

\subsubsection{Técnica de gestão sem forma preestabelecida pelo legislador}

A cooperação judiciária consubstancia-se em atos de gestão atípicos que visam à solução ótima de cada processo e à efetividade do funcionamento do Judiciário, razão pela qual o legislador não estabeleceu regras procedimentais predeterminadas para sua realização.

Conforme o artigo 69 do CPC, o ato de cooperação "prescinde de forma específica"²1. O legislador abriu um espaço de liberdade aos juízos, a fim de permitir "uma atuação adequada dos sujeitos processuais sob o ponto de vista da efetividade do processo e da eficiência da Jurisdição" (Lunardi, 2018, p. 169). Essa é a "beleza da norma: sua flexibilidade, permitindo-se seu manuseio livre pelo órgão jurisdicional conforme a necessidade observada no caso concreto" (Wambier, Conceição, Ribeiro, \& Mello, 2016, p. 152).

O ato de cooperação é uma técnica cujo objetivo é concretizar o direito fundamental a um processo efetivo (Ferreira, 2019, p. 26). Atribuem-se poderes ao magistrado para que, na busca da eficiência, possa gerir a demanda, diante do caso concreto, a fim de obter a efetividade da decisão judicial.

Sendo um ato de gestão processual, não há delimitação do objeto do pedido de cooperação entre os juízos (CPC, art. 68). O pedido de cooperação, que prescinde de forma específica ${ }^{22}$, pode ser executado por auxílio direto - prestação de informações, atos conjuntos - reunião ou apensamento de processos, ou por atos concertados (CPC, arts. 68 e 69 e Recomendação n. ${ }^{\circ}$ 350/2020 do CNJ, art. 8..$\left.^{\circ}\right)^{23}$. O legislador não estabeleceu uma regra predeterminada, pois a cooperação é uma técnica em prol da eficiência na administração judiciária voltada para a concretização de um processo efetivo. A efetividade do ato de cooperação somente pode ser alcançada com a flexibilidade das suas regras.

\subsubsection{Dos atos de cooperação: atos únicos e atos permanentes (atos concertados)}

Os atos de cooperação podem ser executados como: a) auxílio direto - prestação de informações; b) atos conjuntos reunião ou apensamento de processos; c) atos concertados (CPC, arts. 68 e 69 e Recomendação n. ${ }^{\circ} 350 / 2020$ do CNJ, art. $8 .^{\circ}$ ).

\footnotetext{
${ }^{20}$ Ver item 3.3.2.2

${ }^{21}$ A doutrina enfatiza que o ato de cooperação não tem uma forma específica, com suporte no dispositivo do CPC: Câmara, 2018, p. 59, Marinoni, et al., 2017 b, p. 31.

22 “O ato de cooperação, por sua vez, 'prescinde de forma específica'. Logo, ele tanto pode ser formalizado mediante ato individualizado, convênios, atos regulamentares, regimento interno, resoluções etc., como podem ser pactuados de modo informal, inclusive verbalmente” (Meireles, 2015, p. 63).

${ }^{23}$ Recomendação n. ${ }^{\circ}$ 350/2020 do CNJ: “Art. 8. ${ }^{\circ}$ O pedido de cooperação judiciária deve ser prontamente atendido, prescinde de forma específica e pode ser executado por auxílio direto (Anexo I), por atos conjuntos (Anexo II), ou concertados (Anexo III) entre os juízes cooperantes. $\S 1 .^{\circ}$ O processamento dos pedidos de cooperação será informado pelos princípios da celeridade, da concisão, da instrumentalidade das formas e da unidade da jurisdição nacional, dando-se prioridade ao uso dos meios eletrônicos; $§ 2 .^{\circ}$ Os atos e pedidos de cooperação judiciária deverão ser realizados de forma fundamentada, objetiva e imparcial".
} 
Trata-se de hipóteses cujos procedimentos ou modos de realização não estão expressamente previstos pela lei ${ }^{24}$, porque o que se visa é permitir uma maior flexibilização pelos órgãos do Poder Judiciário, a fim de que se possa atingir maior eficiência e efetividade na prestação jurisdicional.

Há uma gradação na ordem estabelecida pelo legislador, conforme a complexidade do ato, que se inicia com o auxílio direto, o qual pode ser realizado sem maiores formalidades, e vai até o ato mais complexo, que é o ato concertado, que ocorre entre juízos ou órgãos do Poder Judiciário de forma permanente.

A cooperação pode ocorrer para a realização de um determinado ato isolado - por exemplo, a citação em um processo (auxílio direto) ou a reunião de processos visando a realização de atos processuais (ato em conjunto), inerentes apenas àquela(s) causa(s) -, caso em que, finda a causa, cessa a cooperação, mas também pode dar-se para a realização de atos de forma permanente entre os juízos ${ }^{25}$ - os atos concertados.

Os atos de cooperação, portanto, podem ocorrer caso a caso ou mediante acordos de forma permanente, com a realização de atos concertados, para gerar eficiência para o processo e para a gestão judiciária. Assim, por meio da cooperação judiciária, os juízes podem praticar atos únicos, ou não, realizados em um determinado processo, ou processos, de forma episódica, o que deverão fazer em decisão fundamentada, ou atos que aproveitem a mais de um processo de forma permanente, mediante um acordo prévio (ato concertado). O auxílio direto e a prestação de informações, por exemplo, são atos de cooperação que podem ocorrer de forma única, isolada, para um determinado processo, ou de forma permanente, mediante ato concertado.

$\mathrm{O}$ artigo 69 , I, do CPC $^{26}$ prevê que a cooperação judiciária pode-se dar por auxílio direto. Nessa hipótese, o cumprimento de um ato processual é feito sem maior formalidade legal ou juízo de delibação. Assim, na esfera da cooperação internacional, um ato pode ser praticado por um órgão, em cooperação com outro, sem que haja necessidade de maiores formalidades ou do exercício do juízo de admissibilidade (Meireles, 2015, p. 64).

O auxílio direto está previsto no artigo 377 do CPC, que o distingue da carta precatória e da carta rogatória. Trata-se de atos distintos. A carta precatória é um ato de cooperação tipificado na legislação (CPC, art. 267), que exige do juízo deprecado uma conduta cooperante, só podendo haver recusa de cumprimento na hipótese prevista em lei; já o auxílio direto é um ato de cooperação atípico, que não está disciplinado expressamente na lei, mas é estabelecido por iniciativa dos órgãos do Poder Judiciário (Meireles, 2015, p. 63).

A critério dos juízes cooperantes, o auxílio direto pode ser estabelecido como um procedimento para a comunicação dos atos processuais sem que seja necessária a expedição de carta. São exemplos as intimações por meio eletrônico, como por Whatsapp, que não exigem maiores formalidades. É o que ocorre se o autor, não sabendo do endereço do demandado, tem conhecimento de que ele está presente em uma audiência que está sendo realizada na mesma comarca, mas em outro juízo. Nesse caso, o juiz da causa pode solicitar, até por via telefônica, ao juiz do outro Fórum que ele faça a citação ou a intimação no curso da audiência, considerando que o oficial de justiça pode demorar para chegar ao local para realizar a comunicação (Meireles, 2015, p. 73).

O juiz pode solicitar que uma providência seja cumprida como auxílio direito, mediante documentação e encaminhamento por e-mail, bastando a indicação do nome do servidor responsável pela providência solicitada, pedindo, por

\footnotetext{
${ }^{24}$ A Recomendação n. ${ }^{\circ}$ 350/2020 estabelece modelos exemplificativos de pedido de cooperação por auxílio direto (Anexo I), despachos conjuntos (Anexos II) e atos concertados (Anexos III).

25 “A eficiência na troca de informações tanto mais será eficaz se elas forem perenes e constantes. Ou seja, ao invés de firmarem cooperação para determinado processo, melhor será a troca de informações contínua, especialmente quando diante de partes que procuram criar obstáculos à satisfação da decisão judicial" (Meireles, 2015, p. 71).

${ }^{26}$ Recomendação n. ${ }^{\circ}$ 350/2020 do CNJ, art. 8. : “' "O pedido de cooperação judiciária [...] pode ser executado por auxílio direto (Anexo I) [...] entre os juízes cooperantes".
} 
exemplo, a intimação de uma testemunha pra prestar depoimento em um processo, encaminhamento de cópia integral dos autos, penhora no rosto dos autos ou encaminhamento de informações.

A cooperação judiciária mediante um pedido de informações (CPC, art. 69, III), pode dar-se seja em relação a processos que tramitam no juízo requerido, seja em relação a recursos pendentes nos tribunais, resultando na maior fluidez, na solução de questões que dependem de informações de outros juízos (Avelino, 2015, p. 193). São exemplos as informações sobre o endereço das partes e das testemunhas, a realização de uma inspeção judicial, o local onde se encontram os bens do devedor, a avaliação do bem penhorado etc. (Meireles, 2015, p. 71).

A prestação de informações pode imprimir maior eficiência ao Judiciário, principalmente na fase de cumprimento da sentença ou de execução, acerca da localização de bens do devedor. Trata-se não de obtenção de provas, mas meramente de informações que podem ser úteis para a realização dos atos processuais. É o caso do credor que oferece um novo endereço do devedor, e o juiz, antes de mandar notificar o devedor no novo endereço, pede informações a outro juízo, que também processa demanda contra a mesma pessoa, sobre a localização do demandado, evitando, assim, a realização de uma diligência inútil (Meireles, 2015, p. 70-71).

O pedido de cooperação por ser executado por atos $\operatorname{conjuntos}^{27}$. O artigo 69, II, do CPC prevê a possibilidade de reunião de processos por ato de cooperação entre os juízes. A reunião, nesses casos, dar-se-á para reger situações episódicas em que o julgador vislumbre a possibilidade de uma melhor eficiência na prestação da tutela jurisdicional. Não se trata de um ato permanente, mas de ato(s) que visa(m) otimizar a prestação jurisdicional em situações concretas que se apresentam ao julgador, de atos que visam aperfeiçoar a prestação jurisdicional de um processo específico.

Finalmente, o artigo 69, IV, do CPC $^{28}$ prevê que a cooperação entre juízes cooperantes pode realizar-se mediante atos concertados.

O ato concertado não é um ato de cooperação entre juízos ou órgãos do Poder Judiciário, único e exclusivo para um determinado processo ou caso concreto; são atos permanentes, pelos quais os juízes poderão estabelecer procedimento para a prática de atos prévios para melhor gerir processos e alcançar maior eficiência, mas nada impede sejam criados no curso de um processo para gerar eficiência para o processo e para a gestão judiciária (Ferreira, 2019, p. 27).

$\mathrm{O}$ ato concertado pode visar a prática de qualquer ato processual (CPC, art. 68), tendo como objeto a condução, a instrução, a execução e a decisão $0^{29}$. O artigo $69, \S 2 .^{\circ}$, do CPC apresenta um rol exemplificativo de atos concertados, sem prejuízo, portanto, de outros atos compatíveis com o mesmo propósito do instituto ${ }^{30}$.

Conforme o referido dispositivo, o ato concertado pode estabelecer procedimentos para: a) a prática de citação, intimação ou notificação de atos processuais (nas localidades onde não houver vara do trabalho, por exemplo, pode ser estabelecido um ato concertado para que o juiz da justiça comum realize a citação ou a intimação dos sujeitos ${ }^{31}$ ); b) a obtenção e apresentação de provas e a coleta de depoimentos (por exemplo, pode ser realizado um ato concertado para a produção de uma única prova comum a diversos processos ${ }^{32}$, como a colheita de uma prova testemunhal); c) atos tendentes à efetivação de

\footnotetext{
${ }^{27}$ Recomendação n. ${ }^{\circ}$ 350/2020 do CNJ, art. 8. . “"O pedido de cooperação judiciária [...] pode ser executado por [...] atos conjuntos (Anexo II) [...] entre os juízes cooperantes".

${ }^{28}$ Recomendação n. ${ }^{\circ}$ 350/2020 do CNJ, art. 8. ${ }^{\text {o: }}$ "O pedido de cooperação judiciária [...] pode ser executado por [...] atos concertados (Anexo III) entre os juízes cooperantes".

${ }^{29}$ Ver item 3.3.2.3

${ }^{30} \mathrm{O}$ artigo $6^{\circ}$ da Recomendação n. ${ }^{\circ}$ 350/2020 do CNJ estatui um rol exemplificativo de atos de cooperação com dezenove incisos.

31 “[...] podemos mencionar a hipótese de ato cooperante para que juízes de ‘justiças’ distintas realizem o ato de comunicação. Vejam que o parágrafo único do art. 237 do CPC/2015 estabelece que 'se o ato relativo a processo em curso na Justiça federal ou em tribunal superior houver de ser praticado em local onde não haja vara federal, a carta poderá ser dirigida ao juízo estadual da respectiva comarca"” (Meireles, 2015, p. 72).

32 "Imagine-se, por exemplo, um produto que se suponha nocivo à saúde e que possa ter prejudicado diversos consumidores. Qual o sentido de se produzir prova pericial em cada um desses processos para o mesmo objetivo? Não é mais delegar a apenas um magistrado a colheita dessa prova (por hipótese, àquele mais próximo do objeto da perícia), para depois transportar essa prova - e eventualmente outras que se mostrem pertinentes - aos outros processos?" (Marinoni, et al., 2017b, p. 32). Ver também: Câmara, 2018, p. 60-61, Lunardi, 2018, p. 176.
} 
tutela provisória, de medidas e providências para recuperação e preservação de empresas e à facilitação de habilitação de créditos na falência e na recuperação judicial; d) atos para execução de decisão jurisdicional (como já ocorre no procedimento executivo, quando há diversas execuções contra o mesmo executado, caso em que é possível concentrar num só juízo a penhora de todos os bens, ou quando da realização de leilão judicial num mesmo processo, permitindo maior precisão na investigação patrimonial e na excussão dos bens, o que torna a execução mais eficiente, com redução de custos); f) a centralização de processos repetitivos (objeto de estudo específico mais adiante).

O ato concertado é, assim, um ato de cooperação judiciária permanente. Trata-se de acordo atípico (Ferreira, 2019, p. 27) entre dois ou mais juízes ou entre órgãos do Judiciário, que, na sua função de gestores, regulamentam uma relação permanente entre os juízos cooperantes para uma melhor efetividade da prestação jurisdicional.

\subsection{Modificação da competência para evitar decisões conflitantes por ato de cooperação judicial}

\subsubsection{A modificação da competência no CPC de 2015 e a eficiência processual}

A modificação de competência foi disciplinada no CPC de 2015 com alterações substanciais em relação ao sistema anterior, mostrando o legislador preocupado com a eficiência da prestação jurisdicional, atendendo em parte ao que a doutrina já aduzia ${ }^{33}$.

Mantendo a tradição em nosso sistema, o artigo 55 do CPC estatui que os processos serão reunidos para decisão conjunta quando lhes for comum "o pedido ou a causa de pedir". O dispositivo refere-se às hipóteses de conexão fundadas na afinidade de pedido e causa de pedir, já previstas desde o CPC de 1939, ainda que naquele momento as opções fossem mais $\operatorname{amplas}^{34}$.

Além da conexão, manteve o CPC a previsão da continência, uma espécie de conexão de maior amplitude, que ocorre quando há identidade quanto às partes e à causa de pedir, mas o pedido de uma, por ser mais amplo, abrange o das demais (CPC, art. 56).

A conexão e a continência justificam-se pela possibilidade de decisões conflitantes. Mas o CPC de 2015 foi mais além, privilegiando a reunião de processos para evitar decisões antagônicas ainda que entre eles não haja a conexão, para dar concretude a um sistema de precedentes que preconiza a uniformidade de decisões.

Assim, o CPC de 2015 admite a reunião de processos que versem sobre a mesma relação de direito material, ainda que não tenham identidade de pedido ou de causa de pedir, como ocorre na "execução de título extrajudicial e [na] ação de conhecimento relativa ao mesmo ato jurídico" e nas "execuções fundadas no mesmo título executivo" (CPC, art. 55, § 2. ${ }^{\circ}$, I e II).

Para corroborar que o objetivo preconizado sistemicamente é a uniformidade das decisões, estatuiu o CPC no $\S 3 .^{\circ}$ do mesmo artigo 55: "Serão reunidos para julgamento conjunto os processos que possam gerar risco de prolação de decisões conflitantes ou contraditórias caso decididos separadamente, mesmo sem conexão entre eles".

A opção do legislador é evitar a dissonância entre decisões, devendo as ações serem reunidas mesmo que entre elas não haja identidade de pedido e causa de pedir. Pelo sistema, a reunião das ações deverá ocorrer no juízo prevento (CPC, art. 58), mas, conforme se exporá a seguir, por um ato de cooperação, é possível a reunião das ações no juízo em que a causa foi ajuizada depois.

Vê-se que houve uma ampliação das hipóteses de modificação de competência em relação ao sistema anterior (CPC de 1973), o qual se limitava apenas às hipóteses de reunião de ações por conexão.

\footnotetext{
${ }^{33}$ Ainda sob a égide do CPC de 1973, Terra e Assis (1987, p. 36) chegaram a afirmar que a ação de execução fiscal e a anulatória "devem ser reputadas conexas, porque a conexão deve ser analisada tendo-se em especial conta a possibilidade de ocorreram decisões conflitantes".

${ }^{34}$ Artigo 134, § 2. ${ }^{\circ}$, do CPC de 1939: "Havendo mais de um réu e sendo diferentes seus domicílios, poderão ser demandados no foro de qualquer deles, se houver conexão quanto ao objeto da demanda ou quanto ao título ou fato que lhe sirva de fundamento".
} 
A amplitude do legislador visa atender o princípio da eficiência processual, buscando evitar decisões conflitantes e contraditórias, para uma melhor prestação da tutela jurisdicional.

$\mathrm{Na}$ execução, o panorama tem sido modificado paulatinamente. A Lei n. ${ }^{\circ} 11.232$, de 2005, já havia trazido alterações nesse sentido. A partir de 2005, passou-se a admitir, em caso de cumprimento da sentença, a modificação de competência para que a execução se processe no juízo onde será mais fácil a localização e a realização dos atos de constrição dos bens do executado, tendo claramente em vista a maior eficiência nos atos executórios ${ }^{35}$.

Seguindo a mesma linha, o CPC de 2015 (art. 516, parágrafo único) admite a possibilidade de o credor pedir a modificação de competência em caso de cumprimento da sentença. Trata-se da hipótese na qual o "exequente poderá optar pelo juízo do atual domicílio do executado, pelo juízo do local onde se encontrem os bens sujeitos à execução ou pelo juízo do local onde deva ser executada a obrigação de fazer ou de não fazer" em vez de ser no "juízo que decidiu a causa no primeiro grau de jurisdição" (CPC, art. 516, II).

A modificação da competência para a realização dos atos executivos tem por finalidade conferir maior eficiência à execução, com redução de custos e maior precisão na investigação patrimonial e na excussão dos bens, atingindo maior eficiência na prestação da tutela executiva.

Em suma, a competência é um conceito que tem ganhado mais amplitude em nosso sistema em atendimento ao princípio da eficiência processual, com alargamento das suas hipóteses, afastando-se paulatinamente do sistema tradicional, que exigia a identidade do pedido e da causa de pedir como condição exclusiva para sua modificação. No novo cenário do sistema processual, que admite a modificação de competência para evitar decisões conflitantes (CPC, art. $\left.55, \S 3 .^{\circ}\right)$, insere-se o ato de cooperação, conforme será desenvolvido na seção seguinte.

\subsubsection{A modificação de competência para evitar decisões conflitantes por ato de cooperação (único ou permanente)}

Como visto, a cooperação pode dar-se mediante a prática de atos de cooperação únicos, para atender a situações específicas, isoladas, ou mediante atos de cooperação permanente, chamados atos concertados, para disciplinar procedimentos em caráter permanente, fixando uma relação duradoura entre os juízes ou órgãos cooperantes.

A modificação de competência por ato de cooperação, igualmente, pode ocorrer para "reunião ou apensamento de processos", para atender uma situação isolada, e também para a "centralização de processos repetitivos", por ato concertado, para reger situações de cooperação permanente (CPC, art. 69, II, e $\S 2 .^{\circ}$, VI; Recomendação n. ${ }^{\circ} 350 / 2020$-CNJ, art. $6 .^{\circ}$, IV e X, 1 a $^{a}$ parte). Não há dúvida de que a reunião de processos para a prática de atos cooperativos afeta questões de competência, tanto o ato de cooperação realizado para um determinado processo, quanto em caráter permanente, quando se trata de concertação de atos para a centralização de processos repetitivos ou produção de prova que enseje reunião de demandas (CPC, art. 69, II, § 2. , II e VI; Recomendação n. ${ }^{\circ} 350 / 2020-\mathrm{CNJ}$, art. 6. ${ }^{\circ}$, IV, VII e X, 1. . parte).

Quando o ato de cooperação é realizado para um determinado processo ou em caráter permanente, a reunião de processos importará em modificação de competência.

O legislador não especificou as hipóteses em que ocorrerá a união dos processos por ato de cooperação único ou ato concertado, nem a fase processual admissível, se na fase de conhecimento ou na de execução. Não disciplinou tampouco se a reunião de processos dar-se-á tão somente para a prática de atos processuais ou se versa também sobre a possibilidade de

\footnotetext{
35 “Art. 475-P. O cumprimento da sentença efetuar-se-á perante: I - os tribunais, nas causas de sua competência originária; II - o juízo que processou a causa no primeiro grau de jurisdição; III - o juízo cível competente, quando se tratar de sentença penal condenatória, de sentença arbitral ou de sentença estrangeira. Parágrafo único. No caso do inciso II do caput deste artigo, o exeqüente poderá optar pelo juízo do local onde se encontram bens sujeitos à expropriação ou

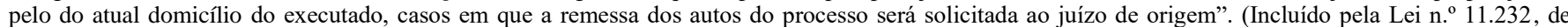
2005).
} 
reunião para julgamento. A abertura normativa permitindo ampla interpretação foi propósito do legislador, uma vez que a cooperação é medida de conveniência e de eficiência, visando uma melhor gestão processual.

\subsubsection{Autorização legal para a modificação de competência por ato de cooperação}

Como se viu, o CPC de 2015 trouxe, inovadoramente, a possibilidade de reunião para julgamento conjunto dos processos que possam gerar risco de prolação de decisões conflitantes ou contraditórias, caso decididos separadamente, mesmo sem conexão entre eles, quebrando a tradição de que a reunião de processos somente poderia ocorrer quando houvesse identidade de pedido e de causa de pedir (CPC, art. 55, § $\left.3 .^{\circ}\right)$.

A reunião de processos por ato de cooperação (único ou permanente) enquadra-se na referida hipótese legal. O intuito do legislador ao permitir nesses casos a reunião de ações - que, embora não tenham identidade de pedido e causa de pedir, podem gerar decisões conflitantes - foi alcançar maior eficiência processual por ato de gestão processual.

Para a reunião dos processos por ato de cooperação, basta que haja a conveniência judiciária do ponto de vista da sua gestão. A reunião por ato de cooperação não exige que se debata sobre a mesma relação jurídica ou sobre o mesmo fato, embora se esteja, na maioria das hipóteses, diante de demandas fundadas sobre o mesmo fato ou relação jurídica base, ainda que diversos sejam os réus (Meireles, 2019, p. 89).

A possibilidade de reunião de processos por ato de cooperação está, assim, autorizada pelo artigo $55, \S 3 .^{\circ}$, do CPC. Contudo, não é um imperativo legal, mas produto de um ato de cooperação entre os juízos, resultado do diálogo entre os juízes e órgãos do Poder Judiciário para responder com eficiência às situações concretas.

A modificação da competência pode dar-se até por vontade de uma das partes ${ }^{36}$. Em se tratando de um ato de gestão processual que objetiva evitar decisões conflitantes, caberá aos juízos cooperantes analisar o juízo que deverá reunir os processos para o melhor desempenho da atividade jurisdicional. Logo, não sendo um imperativo legal, mas fruto do diálogo entre os juízos, a reunião das ações ocorrerá não no juízo prevento (CPC, art. 58), mas no juízo que, em análise pelos juízos cooperantes, permite a melhor prestação da tutela jurisdicional.

Trata-se, pois, de uma hipótese de modificação de competência autorizada pelo sistema, mas não imposta pela lei ${ }^{37}$. Desse modo, diferentemente daquelas que decorrem da lei, a escolha do juízo competente dependerá de um juízo de ponderação feito pelo(s) órgão(s) judiciário(s).

A questão não é nova.

A possibilidade de alteração da competência como uma faculdade outorgada ao juiz em um juízo de ponderação e argumentativo não é uma novidade em nosso sistema.

A Lei de Execuções Fiscais (LEF) - Lei n. ${ }^{\circ}$ 6.830/1980 - prevê, em seu artigo 28, que "o juiz, a requerimento das partes, poderá, por conveniência da unidade da garantia da execução, ordenar a reunião de processos contra o mesmo

\footnotetext{
${ }^{36}$ De acordo com o artigo 63 do CPC, as partes "podem modificar a competência em razão do valor e do território, elegendo foro onde será proposta ação oriunda de direitos e obrigações"; já o artigo 65 prevê que a competência relativa será prorrogada "se o réu não alegar a incompetência em preliminar de contestação", que ocorre quando o autor escolhe para ajuizamento da ação um foro que não tem legalmente competência e, no entanto, o réu o aceita tacitamente, deixando de alegar, em preliminar de contestação, a incompetência.

${ }^{37}$ Em sentido contrário, há quem defenda a impossibilidade da alteração de competência por ato de cooperação: “Os pedidos de cooperação jurisdicional não servem à modificação do procedimento. Em verdade, ainda que haja a consagração do princípio da adequação processual no Novo Código de Processo Civil (arts. 139, VI), sob as vestes de cooperação judicial não se pode criar ou suprimir etapas sem que haja autorização expressa no regramento geral do Código ou em negócio processual (art. 190 do NCPC). A cooperação aqui é para a prática de atos processuais, com o escopo de efetivá-los de forma mais eficiente, não para alterar, de forma indevida, o procedimento" (Avelino, 2015, p. 189); "Não há no sistema brasileiro norma que imponha a reunião de demandas para julgamento de questões comuns de fato ou de direito para além dos citados mecanismos. A conexão, uma das hipóteses dessa agregação, possibilita o julgamento conjunto apenas nos casos em que houver fato único comum à sustentação de várias pretensões. A reunião em caso de conexão, portanto, não será admitida quando o fato for diverso para cada um dos envolvidos, ou mesmo quando, em se tratando de fato comum, o número de atingidos for tão elevado que inviabilize essa reunião. Remanesce, como se vê, o problema do tratamento e solução conjuntos de fatos que, embora não únicos, sejam comuns [...]. Para esses casos - em que se está diante de questão comum de fato, mas decorrente de vários fatos semelhantes, resta apenas, ao menos numa análise de lege lata, a reunião de demandas para produção de prova comum, já que o sistema brasileiro não autoriza a agregação para julgamento conjunto de questões comuns de fato. A hipótese, que é de afinidade e não de conexão, se justifica à luz do art. $69, \S 2 .^{\circ}$, do CPC, ou seja, decorre das previsões, insertas no Código de Processo Civil de 2015, voltadas à cooperação nacional entre juízes por meio da prática de atos concertados" (Lunardi, 2018, p. 165-166).
} 
devedor". Em caso de deferimento do pedido, "os processos serão redistribuídos ao juízo da primeira distribuição" (LEF, art. 28, parágrafo único). Sobre o tema, o Superior Tribunal de Justiça (STJ), no Recurso Especial (REsp) 1.158.766/RJ ${ }^{38}$, submetido à sistemática dos recursos repetitivos (CPC/1973, art. 543-C), consolidou o entendimento de que a reunião de processos contra o mesmo devedor, nos termos do artigo 28 da Lei n. ${ }^{\circ} 6.830 / 1980$, é uma faculdade outorgada ao juiz. Inteligência da Súmula 515 do STJ.

O CPC de 2015 reforça essa possibilidade que já vinha sendo admitida na jurisprudência.

Contudo, diferentemente do que ocorre no executivo fiscal, onde é obrigatória a reunião dos processos quando há "identidade das partes nos feitos a serem reunidos", o ato de cooperação não exige a identidade das partes, admitindo-se a reunião ou o apensamento de processos ainda que as partes sejam diversas ${ }^{39}$.

A conveniência judiciária para a escolha do juízo em que serão reunidos os processos fica ainda mais contundente quando se trata de um ato concertado para a centralização de processos repetitivos (CPC, art. $69, \S 2 .^{\circ}$; Recomendação n. ${ }^{\circ}$ 350/2020-CNJ, art. $6 .^{\circ}, \mathrm{X}, 1^{\mathrm{a}}{ }^{\mathrm{a}}$ parte), uma vez que se trata de situações em que se deverão identificar características da litigiosidade, a fim de traçar coletivamente uma política judiciária adequada à realidade.

Ao usar o termo "processo repetitivo", o legislador quis afastar a reunião de processos por conexão ou continência, deixando claro que a centralização de processos por ato concertado é algo diferente dos casos tipificados (CPC, art. 55, § $3 .^{\circ}$ ). O processo repetitivo, que permite a centralização de processos por ato concertado, não precisa ter a mesma causa de pedir ou o mesmo pedido. A repetição pode ocorrer em razão de um determinado fato, ainda que não haja nem mesmo um ponto comum de direito, ou mesmo por afinidade de questões de direito. Não há necessidade de que os fatos sejam exatamente iguais, mas basta que possam ter alguma correlação de modo a gerar decisões controvertidas.

Assim, mesmo que não haja identidade do pedido ou da causa de pedir ou que a relação jurídica seja bem diversa, mas haja risco de decisões divergentes não contraditórias, é possível a reunião de demandas para o julgamento simultâneo com base

\footnotetext{
38 “1. A reunião de processos contra o mesmo devedor, por conveniência da unidade da garantia da execução, nos termos do art. 28 da Lei $6.830 / 80$, é uma faculdade outorgada ao juiz, e não um dever [...]. 2. O artigo 28, da lei 6.830/80, dispõe: 'Art. 28 - O Juiz, a requerimento das partes, poderá, por conveniência da unidade da garantia da execução, ordenar a reunião de processos contra o mesmo devedor.' 3 . A cumulação de demandas executivas é medida de economia processual, objetivando a prática de atos únicos que aproveitem a mais de um processo executivo, desde que preenchidos os requisitos previstos no art. 573 do CPC c/c art. 28, da Lei 6.830/80, quais sejam: (i) identidade das partes nos feitos a serem reunidos; (ii) requerimento de pelo menos uma das partes (Precedente: Resp 217948/SP, Rel. Min. Franciulli Netto, DJ 02/05/2000); (iii) estarem os feitos em fases processuais análogas; (iv) competência do juízo [...]. 5. [...] há que se distinguir duas situações, porquanto geradoras de efeitos diversos: (i) a cumulação inicial de pedidos (títulos executivos) em uma única execução fiscal, por aplicação subsidiária das regras dos arts. 292 e 576 do CPC, em que a petição inicial do executivo fiscal deve ser acompanhada das diversas certidões de dívida ativa; (ii) a cumulação superveniente, advinda da cumulação de várias ações executivas (reunião de processos), que vinham, até então, tramitando isoladamente, consoante previsão do art. 28, da Lei 6.830/80. 6. A cumulação de pedidos em executivo fiscal único revela-se um direito subjetivo do exequente, desde que atendidos os pressupostos legais. (Precedentes: REsp 1110488/SP, Rel. Ministro BENEDITO GONÇALVES, PRIMEIRA TURMA, julgado em 25/08/2009, DJe 09/09/2009; REsp 988397/SP, Rel. Ministra ELIANA CALMON, SEGUNDA TURMA, julgado em 05/08/2008, DJe 01/09/2008; REsp 871.617/SP, Rel. Ministro LUIZ FUX, PRIMEIRA TURMA, julgado em 25/03/2008, DJe 14/04/2008). 7. Ao revés, a reunião de diversos processos executivos, pela dicção do art. 28, da LEF, ressoa como uma faculdade do órgão jurisdicional, não se tratando de regra cogente, máxime em face do necessário juízo de conveniência ou não da medida, o que é aferível casuisticamente. [...]” (STJ. (1. Seção). REsp 1.158.766/RJ. Relator: Min. Luiz Fux. Julgado em: 08/09/2010. DJe 22/09/2010). No mesmo sentido, cf.: “[...] Esta Corte entende ser faculdade do juízo a reunião de processos conforme dicção do art. 28 da Lei 6.830/1980, não se tratando de regra cogente, máxime em razão do necessário juízo de conveniência ou não da medida, o que é aferível casuisticamente [...]" (STJ (1. Turma). AgInt no REsp 1452451/SC. Relator: Min. Napoleão Nunes Maia Filho. Julgado em: 23/09/2019. DJe 30/09/2019). Cf. ainda: STJ (1. Turma). REsp 1125387/SP. Relator: Min. Luiz Fux. Julgado em: 08/09/2009. DJe 08/10/2009; STJ (1. Turma). AgRg no REsp 609.066/PR. Relatora: Min. Denise Arruda. Julgado em: 21/09/2006. DJ 19/10/2006; STJ (2. Turma). EDcl no AgRg no REsp 859.661/RS. Relator: Min. Humberto Martins. Julgado em: 02/10/2007. DJ 16/10/2007; STJ (2. Turma). REsp 399657/SP. Relator: Min. João Otávio de Noronha. Julgado em: 16/02/2006. DJ 22/03/2006; STJ (2. Turma). AgRg no Ag 288.003/SP. Relatora: Min. Eliana Calmon. Julgado em: 18/05/2000. DJ 01/08/2000; STJ (2. Turma). REsp 62.762/RS. Relator: Min. Adhemar Maciel. Julgado em: 21/11/1996. DJ 16/12/1996.
}

39 “[...] dado o critério de conveniência e eficiência, é muito mais provável que pelo menos haja identidade de uma das partes do processo, isto é, muito provavelmente, por conveniência e eficiência, exige-se que o autor (ou credor) seja o mesmo ou seja o mesmo demandado (ou executado). Dificilmente, na hipótese do inc. II do art. 69 do CPC/2015, estar-se-á diante de um caso em que seja conveniente a reunião de processos nos quais não haja coincidência de qualquer das partes litigantes. Mas não é raro. Basta lembrar das demandas repetitivas contra diversas entidades bancárias com pedido de aplicação do mesmo índice de correção monetária incidente sobre os créditos depositados em cadernetas de poupança. Neste caso, por conveniência, pode-se centralizar os processos repetitivos, já que se debate, em todos eles, a mesma questão jurídica, ainda que diversos os demandados. Portanto, como não há essa restrição, desde que seja conveniente, diante do caso concreto, poder-se-á reunir ou apensar processos mesmo que não haja absoluta identidade de qualquer das partes litigantes" (Meireles, 2019, p. 85) 
no artigo $69, \S 2 .^{.40}$, em um ato concertado, pois se trata de técnica de concretização do princípio da eficiência (Ferreira, 2019, p. 15).

Nesse sentido, a doutrina tem admitido que o ato concertado é hipótese legal de alteração de competência ${ }^{41}$, pois a centralização de processos por ato de cooperação enseja a modificação da competência para o julgamento deles. Trazendo o artigo 69 , § 2. ${ }^{\circ}$, VI, mais uma hipótese de modificação de competência, o juiz, em decisão fundamentada, justificará a modificação de competência, depois de ouvir as partes (CPC, art. 9..$^{\circ}$ (Meireles, 2019, p. 89).

Desse modo, o ato concertado definirá o juízo em que serão reunidas as ações, devendo-se levar em conta a eficiência processual, uma vez que todos os juízos nos quais correm as ações são competentes. Assim como ocorre nos atos de cooperação para a realização de um ato único, não se deverão seguir as regras de prevenção para determinar o juízo competente por ato concertado ${ }^{42}$, uma vez que a prevenção é regra determinada pelo legislador e o ato concertado apoia-se em regras de ponderação para alcançar uma maior eficiência processual.

Em suma, diante do risco de decisões conflitantes, a lei prevê a possibilidade de mudança de competência por ato formalizado entre os juízes cooperantes, isto é, a competência pode ser modificada por deliberação volitiva dos juízes cooperantes por ato único ou concertado, não havendo ferimento do princípio do juiz natural, mas um juízo de ponderação, privilegiando-se a eficiência na busca da efetividade da decisão judicial ${ }^{43}$.

\subsubsection{Atividade facultativa do julgador e o papel das partes na modificação de competência por ato de cooperação}

O ato de cooperação (único ou concertado) é uma técnica de gestão processual que visa imprimir harmonização e agilização aos procedimentos forenses para alcançar uma prestação jurisdicional mais eficiente. Logo, não há obrigatoriedade para os órgãos do Poder Judiciário, porque o legislador deseja dar maior eficiência ao processo, permitindo a realização de atos indeterminados consensuais de modo a garantir a melhor prestação da tutela jurisdicional.

$\mathrm{O}$ ato de cooperação é, portanto, uma faculdade do julgador ${ }^{44}$, que, na busca pela eficiência, pode fazer acordo de cooperação que importe em modificação de competência com juízos ou órgãos judiciais, para melhor gerir a demanda. Para o acordo de cooperação, em princípio, é despiciendo o pedido das partes, pois a reunião de processos com consequente modificação de competência visa evitar decisões conflitantes e tem razão nos princípios constitucionais da eficiência, da celeridade e da efetividade da decisão judicial (Meireles, 2019, p. 85), mas nada impede que as partes requeiram a realização do ato de cooperação ${ }^{45}$.

Como ato de cooperação que é, deve-se observar o dever de esclarecimento, cabendo ao órgão jurisdicional esclarecer os seus próprios pronunciamentos para as partes, bem como consultar as partes sobre questão não suscitada no processo (Ferreira, 2019, p. 32), devendo sempre intimá-las ${ }^{46}$. O ato de cooperação deve permitir que os sujeitos processuais dos casos envolvidos participem da formação do convencimento do juízo centralizador, visto que o poder de influência, conteúdo do contraditório, deve ser respeitado (Didier Jr., 2020, p. 104).

\footnotetext{
${ }^{40}$ Recomendação n. ${ }^{\circ} 350 / 2020-\mathrm{CNJ}$, art. 6. ${ }^{\circ}, \mathrm{X}, 1 .^{\text {a }}$ parte.

${ }^{41}$ Cf.: Câmara, 2018, p. 61, Campos, 2020, p. 132-133, Didier Jr., 2020, p. 98, Ferreira, 2019, p. 38, Marinoni, Arenhart, \& Mitidiero, 2017b, p. 29. Em sentido contrário, entendem que a reunião de processos pressupõe sempre a conexão ou a continência entre eles: Nery Junior \& Nery, 2015 , p. 368.

${ }^{42}$ Em sentido contrário, admitindo que a reunião deverá ocorrer no juízo prevento: Câmara, 2018, p. 61.

${ }^{43}$ Nesse sentido: Marinoni, et al. 2017b, p. 32, Meireles, 2019, p. 84.

${ }^{44}$ Campos, 2020, p. 126, Meireles, 2019, p. 83. Em sentido contrário, entendendo que a cooperação judiciária é um dever jurídico de recíproca cooperação: Didier Jr., 2020, p. 62-63.

${ }^{45}$ Recomendação n. ${ }^{\circ}$ 350/2020-CNJ: “art 8..$^{\circ}$ (...) 4o Fica deferida às partes e às pessoas naturais ou jurídicas, órgãos ou entidades especializadas, com representatividade adequada, requerer ao juízo a realização de ato de cooperação para as hipóteses previstas nesta Resolução".

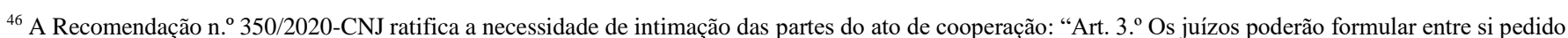
de cooperação para a prática de qualquer ato processual, intimando-se as partes do processo; [...] Art. 5..$^{\circ}$ A cooperação judiciária nacional: [...] V - deve ser comunicada às partes do processo".
} 
Logo, sempre caberá ao juiz, diante do caso concreto, verificar se a reunião pode causar alguma restrição ao direito de acesso à Justiça, devendo questionar as partes, uma vez que a modificação de competência pode resultar em verdadeiro obstáculo ao direito de demandar, como, por exemplo, em casos em que a parte carente de recursos financeiros não poderá acompanhar seu processo em localidade distante daquela onde reside (Meireles, 2029, p. 88).

Enfim, sendo ato de gestão que visa a otimização da prestação da tutela jurisdicional, dependendo da situação concreta, as partes deverão manifestar-se também sobre o ato de cooperação, pois a modificação de competência pode causarlhes prejuízo, inviabilizando a sua participação no processo. Nesses casos, deve ser considerada a realização do ato em outro juízo ou a produção do ato por outro meio. Tudo dependerá do caso concreto, a ser analisado pelo julgador. O juiz deve dialogar com as partes, mas, sem justificativa plausível, não haverá razão para impedir a modificação de competência.

\subsubsection{Objeto da modificação de competência: prática de atos processuais e julgamento da causa}

A modificação de competência para a reunião de processos por atos de cooperação judicial deverá ocorrer tanto para a prática de determinados atos processuais, como para o julgamento da causa ${ }^{47}$. Afinal, a reunião ou o apensamento de processos que versem sobre uma mesma questão de fato ou de direito, em um mesmo juízo, possibilita solução mais célere, isonômica e qualificada dos casos pela participação democrática de mais sujeitos na formação do processo (Ferreira, 2019, p. 25-26).

Do mesmo modo, a modificação de competência por ato concertado para a centralização de processos repetitivos deve-se dar não apenas para a prática de determinados atos processuais, mas principalmente para o julgamento da causa, sob pena de o instituto perder grande parte de sua eficácia.

Como já assentado, por processo repetitivo, deve-se entender a identidade factual ou mesmo de questões jurídicas correlatas. Trata-se da reunião de questões comuns semelhantes ou de algum modo relacionadas entre si. São casos semelhantes, mesmo sem conexão entre si, mas reunidos por uma identidade substancial nas teses jurídicas discutidas e nos fatos suscitados (Didier Jr., 2020, p. 99), como, por exemplo, vários consumidores que sofreram danos decorrentes de um mesmo produto, mulheres que consumiram contraceptivo falso, trabalhadores expostos aos mesmos agentes nocivos (Ferreira, 2019, p. 40).

É curial que, com o ato concertado, os juízes cooperantes estabeleçam procedimentos para que os processos repetitivos sejam reunidos em um único juízo a fim de serem processados e julgados evitando decisões conflitantes.

São processos que, mesmo sem conexão entre si, apresentam questões de fato ou de direito de algum modo relacionadas entre $\mathrm{si}^{48}$. O julgamento em um único juízo, mediante ato concertado, evitará a prolação de decisões conflitantes, geradoras de insegurança jurídica e violadoras do princípio da igualdade. Por isso, para a reunião dos processos por ato de cooperação, basta que haja a conveniência judiciária do ponto de vista da sua gestão.

\subsubsection{Questões procedimentais relativas à modificação de competência por ato de cooperação}

Há um consenso na doutrina ${ }^{49}$ segundo o qual a reunião de processos deve ocorrer entre juízes da mesma competência relativa, sendo incabível em se tratando de competência absoluta, uma vez que, nem por convenção das partes, é admissível a mudança de competência em razão da matéria, da pessoa ou da função (CPC, art. 62).

\footnotetext{
${ }^{47}$ Nesse sentido: Ferreira, 2019, p. 34, Meireles, 2015, p. 65. Ver também: Campos, 2020, p. 134-135, Didier Jr., 2020, p. 87, Meireles, 2019, p. 83. Em sentido contrário, não admitindo a possibilidade de cooperação para a prática de atos decisórios: Avelino, 2015, p. 190, Marinoni, Arenhart, \& Mitidiero, 2017a, p. 215.

${ }^{48}$ Registre-se que o termo "processos repetitivos", previsto no artigo $69, \S 2 .{ }^{\circ}, \mathrm{VI}$, do CPC, tem acepção mais ampla do que "demandas repetitivas" ou "casos repetitivos", previstos nos artigos 927 e 928 do CPC (Didier Jr., 2020, p. 92).

${ }^{49}$ Didier Jr., 2020, p. 101, Ferreira, 2019, p. 44, Meireles, 2019, p. 88.
} 
Deve-se admitir que a reunião ou o apensamento de processos possa ocorrer em fases processuais análogas ou até mesmo distintas, mas "tudo dependerá da conveniência e da eficiência da medida, analisada no caso concreto" (Meireles, 2019, p. 86), já que sempre se deverá fazer um juízo de ponderação. Logicamente, a princípio, seria inadequada a reunião dos feitos em tramitação em instâncias distintas, pois seria descabido transferir para o Tribunal o feito de competência de primeiro grau ou deslocar para a primeira instância o processo que já se encontra em fase recursal. Contudo, se os processos se encontrarem na mesma instância, ainda que em fases processuais distintas, pode-se admitir a reunião de ambos com a suspensão daquele mais adiantado para uma decisão conjunta, por exemplo (Meireles, 2019, p. 86).

A identidade do procedimento deve ser dispensada (Meireles, 2019, p. 89), tanto para o ato de cooperação único como para o permanente (ato concertado), considerando que o próprio legislador já a dispensou quando admite a possibilidade de reunião de processos entre a ação executiva e a ação autônoma (CPC, art. 55, § 2. ${ }^{\circ}$, II); além disso, já ocorre com a centralização das execuções contra o mesmo devedor, ainda que os títulos executivos tenham natureza (judicial ou extrajudicial) ou fundamentos diversos.

Com relação aos atos concertados, que visam estabelecer procedimento(s) a ser(em) seguido(s) em vários casos, embora as regras acerca dos atos de concertação sejam prévias, criadas em caráter permanente para gerar eficiência para o processo e para a gestão judiciária, mediante acordos para a prática de atos que aproveitem mais de um processo, nada impede que sejam realizados atos de cooperação caso a caso, nas situações não disciplinadas nos atos de concertação.

Outra questão suscitada acerca da reunião de processos por ato de cooperação é atinente à seara recursal. Como não se trata de juízos incompetentes ${ }^{50}$, pois todos são competentes para julgarem a causa, uma vez definido por ato de cooperação o juízo onde os processos deverão ser reunidos, ali se devem concentrar todos os recursos. Fixada a competência por ato de cooperação, naquele juízo tramitará a ação, concentrando todos os atos e impugnações ${ }^{51}$.

\section{Conclusão}

A eficiência é a capacidade de prestar uma tutela jurisdicional adequada às necessidades do direito material, com o menor custo possível, garantindo a adequada participação das partes e o respeito aos direitos fundamentais. Para atingi-la, são necessários mecanismos de gestão de processos dinâmicos e flexíveis, que promovam o bom desenvolvimento do processo.

A aplicação das técnicas de gestão processual corresponde à observância do princípio da eficiência jurisdicional, o que pode tornar o processo mais rápido, justo e menos custoso e propiciar, como corolário, uma prestação jurisdicional efetiva. A cooperação judiciária, prevista no CPC de 2015, é uma das técnicas de gerenciamento.

Como técnica de gestão processual, a cooperação judiciária pressupõe o diálogo entre os juízes e órgãos do Poder Judiciário para que possam, de modo eficiente e diante de cada caso concreto, alcançar a prestação da tutela jurisdicional de forma mais célere e efetiva, evitando a prática de atos inúteis ou repetitivos. A cooperação judiciária consubstancia-se em atos de gestão atípicos que visam à solução ótima de cada processo e à efetividade do funcionamento do Judiciário, razão pela qual o legislador não estabeleceu regras procedimentais predeterminadas para sua realização.

A reunião de processos por atos de cooperação pode dar-se mediante a prática de atos de cooperação únicos, para atender a situações específicas, isoladas, ou mediante atos de cooperação permanente, chamados atos concertados, para

\footnotetext{
50 “[...] na hipótese de reunião de processos ou centralização de processos repetitivos por cooperação, não se está ante uma situação na qual, diante da demanda in concreto, o juiz seja incompetente. [...] o juízo que declina da competência a tem em tese e diante do caso concreto. O específico processo é de sua competência desde a distribuição ou por fato superveniente. Mas, ainda assim, mesmo sendo o competente diante do caso concreto, por ato de cooperação, ele pode declinar da competência em favor de outro juízo que não a detém no caso concreto, passando a tê-la" (Meireles, 2019, p. 90).

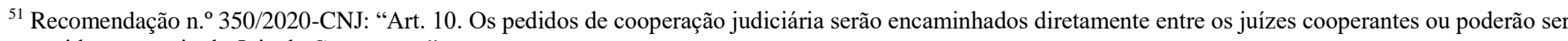
remetidos por meio do Juiz de Cooperação".
} 
disciplinar procedimentos em caráter permanente, fixando uma relação duradoura entre os juízes ou órgãos cooperantes. Em qualquer situação, a reunião de processos para a prática de atos cooperativos afeta questões de competência.

A possibilidade de reunião, por ato de cooperação (único ou concertado), para julgamento conjunto dos processos que podem gerar risco de prolação de decisões conflitantes ou contraditórias, caso decididos separadamente, sem que haja identidade de pedido e de causa de pedir entre eles, está albergada pelo CPC de 2015, o qual quebrou a tradição em nosso sistema que exigia a necessidade de conexão para permitir a reunião de processos (CPC, art. 55, § 3. $\left.{ }^{\circ}\right)$.

O legislador não especificou as hipóteses em que ocorrerá a reunião dos processos por ato de cooperação único ou ato concertado, uma vez que a cooperação é medida de conveniência e eficiência. Ao permitir nesses casos a reunião de ações que, embora não tenham identidade de pedido e causa de pedir, podem gerar decisões conflitantes -, o intuito do legislador foi alcançar maior eficiência processual por ato de gestão processual.

Contudo, embora a reunião de processos por ato de cooperação esteja autorizada pelo artigo $55, \S 3 .^{\circ}$, do CPC, não é um imperativo legal; trata-se de uma nova hipótese de reunião de processos como produto de um ato de cooperação entre os juízos, resultado do diálogo entre os juízes e órgãos do Poder Judiciário para atender com eficiência as situações concretas, cabendo aos juízos cooperantes analisar o local onde deverão se reunir os processos para o melhor desempenho da atividade jurisdicional.

Por conseguinte, não sendo um imperativo legal, sendo antes fruto do diálogo entre os juízos, a reunião das ações ocorrerá não no juízo prevento (CPC, art. 58), mas no juízo que, em análise pelos juízos cooperantes, permite a melhor prestação da tutela jurisdicional, devendo-se admitir que se trata de uma hipótese de modificação de competência autorizada pelo sistema, não imposta, porém, pela lei, que deverá ocorrer tanto para a prática de determinados atos processuais, como para o julgamento da causa, a depender de um juízo de ponderação entre o(s) órgão(s) judiciário(s).

Uma vez fixada a competência do juízo por ato de cooperação, concentrar-se-ão nele todos os recursos e impugnações.

Como ato de otimização da prestação da tutela jurisdicional, não deverá ser descartada a reunião de processos em fases processuais distintas, uma vez que há sempre a possibilidade de suspensão do processo mais adiantado para uma decisão conjunta.

Por fim, sendo o ato de cooperação produto de diálogo, as partes deverão manifestar-se acerca dele, uma vez que a modificação de competência pode causar-lhes prejuízo, inviabilizando a sua participação no processo.

\section{Referências}

Avelino, M. T. (2015). Breves comentários à cooperação nacional no Código de Processo Civil. Revista Jurídica da Seção Judiciária de Pernambuco, 8, 187196.

Ávila, H. (2005). Moralidade, razoabilidade e eficiência na atividade administrativa. Revista Eletrônica de Direito do Estado, 4, 1-25. http://www.direitodoestado.com.br/codrevista.asp?cod=67.

Câmara, A. F. (2018). O novo processo civil brasileiro. (4a ed.): Atlas.

Campos, E. L. C. (2018). O princípio da eficiência no processo civil brasileiro: Forense.

Campos, M. G. (2020). O compartilhamento de competências no processo civil: um estudo do sistema de competências sob o paradigma da cooperação nacional: JusPodivm.

Conselho Nacional de Justiça (2020). Justiça em números 2020: CNJ.

Cunha, L. C. da. (2014). A previsão do princípio da eficiência no projeto do novo Código de Processo Civil brasileiro. Revista de Processo, 39(233), 65-84.

Didier Jr., F. (2020). Cooperação judiciária nacional: esboço de uma teoria para o Direito brasileiro (arts. 67-69, CPC): JusPodivm.

Didier Jr., F. (2017). Curso de direito processual civil. (19a ed.): JusPodivm.

Ferreira, G. M. (2019). O ato concertado entre juízes cooperantes: esboço de uma teoria para o Direito brasileiro. Civil Procedure Review, 10(3), 11-48. 
Research, Society and Development, v. 10, n. 4, e42510414197, 2021

(CC BY 4.0) | ISSN 2525-3409 | DOI: http://dx.doi.org/10.33448/rsd-v10i4.14197

Godoy, A. S. (1995). Introdução à pesquisa qualitativa e suas possibilidades. RAE-Revista de Administração de Empresas, 35(2), 57-63.

Jobim, M. F. (2017). As funções da eficiência no processo civil brasileiro: Revista dos Tribunais.

Lunardi, T. A. P. (2018). Coletivização da prova: técnicas de produção coletiva da prova e seus reflexos na esfera individual. (Tese de doutorado). Universidade Federal do Paraná, Curitiba, PR, Brasil.

Marconi, M. de A., \& Lakatos, E. M. (2003). Fundamentos de metodologia científica. (5a ed.): Atlas.

Marinoni, L. G., Arenhart, S. C., \& Mitidiero, D. (2017a). Novo Código de Processo Civil comentado. (3a ed.): Revista dos Tribunais.

Marinoni, L. G., Arenhart, S. C., \& Mitidiero, D. (2016). Novo curso de processo civil: teoria do processo civil. (2a ed.): Revista dos Tribunais.

Marinoni, L. G., Arenhart, S. C., \& Mitidiero, D. (2017b). Novo curso de processo civil: tutela dos direitos mediante procedimento comum. (3a. ed.): Revista dos Tribunais.

Matos, J. I., Lopes, J. M., Mendes, L. A., \& Coelho, N. (2015). Manual de gestão judicial: Almedina.

Meireles, E. (2015). Cooperação judiciária nacional. Revista de Processo, 40(249), 59-80.

Meireles, E. (2019). Reunião de processos, cooperação e conflito de competência. Revista de Processo, 44(294), 77-94.

Mesquita, M. (2015). Princípio de gestão processual: o "Santo Graal” do novo processo civil? Revista de Legislação e de Jurisprudência, 3995, 78-108.

Nery Junior, N., \& Nery, R. M. de A. (2015). Comentários ao Código de Processo Civil. Revista dos Tribunais.

Nunes, D. (2012). Precedentes, padronização decisória preventiva e coletivização - paradoxos do sistema jurídico brasileiro: uma abordagem constitucional democrática. In T. A. C. Wambier (Coord.), Direito jurisprudencial (pp. 245-276): Revista dos Tribunais.

Pereira, A. S., Shitsuka, D. M., Parreira, F. J., \& Shitsuka, R. (2018). Metodologia da pesquisa científica. UFSM https://repositorio.ufsm.br/bitstream/handle/1/15824/Lic_Computacao_Metodologia-Pesquisa-Cientifica.pdf?sequence=1.

Rodrigues, M. A. dos S., \& Porto, J. R. S. de M. (2018). Princípio da eficiência processual e o direito à boa jurisdição. Revista de Processo, 43(275), 89-117.

Taruffo, M. (2008). Orality and writing as factors of efficiency in civil litigation. In F. Carpi, \& M. Ortells Ramos (Ed.). Oralidad y escritura en un proceso civil eficiente (pp. 185-204). Valencia: Universidad de Valencia.

Terra, M., \& Assis, C. A. de. (1987). Ação anulatória de débito fiscal. Revista dos Tribunais, 76(626), 34-37.

Wambier, T. A. A., Conceição, M. L. L., Ribeiro, L. F. da S., \& Mello, R. L. T. de (2016). Primeiros comentários ao novo Código de Processo Civil: artigo por artigo: Revista dos Tribunais. 